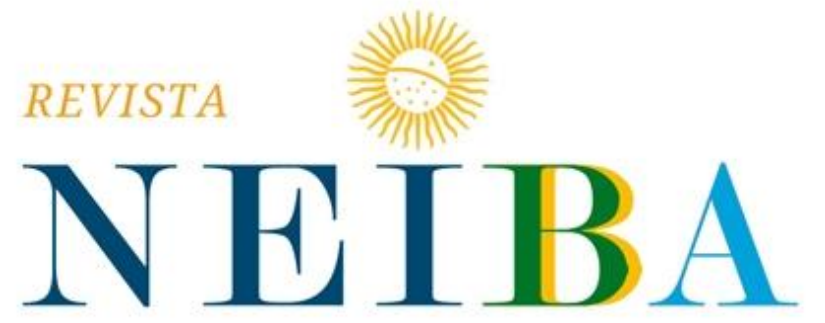

CADERNOS ARGENTINA-BRASIL

Volume 9, 2020, p. 01-36

DOI: 10.12957/neiba.2020.50382 | e50382 I ISSN: 2317-3459

\title{
DA ÁGORA GREGA ÀS ORGANIZAÇÕES INTERNACIONAIS: UM MAPEAMENTO DE MECANISMOS PARTICIPATIVOS
}

FROM GREEK AGORA TO INTERNATIONAL ORGANIZATIONS: A MAPPING OF PARTICIPATORY MECHANISMS

\section{Natanael Gomide Junior ${ }^{1}$}

${ }^{1}$ Universidade Federal de Uberlândia (UFU), Minas Gerais, MG, Brasil. E-mail: natanaelgomidejunior@gmail.com ORCID: https://orcid.org/0000-0003-1399-9928

Recebido em: 21/04/2020 | Aceito em: 01/12/2020. 


\section{RESUMO}

O artigo tem como objetivo apresentar um mapeamento de mecanismos participativos para atores não-estatais em organizações internacionais. Foram pesquisadas 40 instituições e organizações internacionais no que se refere à institucionalização da participação de atores não-estatais. Para atingir o objetivo proposto, recorremos à revisão bibliográfica e à pesquisa documental. A partir da análise, pudemos verificar que a institucionalização de mecanismos participativos na arena internacional remonta à criação do Sistema ONU. Para além disto, concluímos que 77\% das organizações pesquisadas possuem mecanismos institucionalizados de participação social, sendo que a maioria dos mecanismos participativos oferecidos aos atores não-estatais são de caráter consultivo e de colaboração. Também concluímos que a maioria dos mecanismos criados pelas organizações internacionais que foram pesquisadas datam do final da década de 1990 e começo dos anos 2000/2010, sendo que tal fenômeno está intimamente relacionado com a promoção das normas de boa governança, no pósGuerra Fria.

Palavras-chave: Organizações Internacionais; Mecanismos Participativos; Participação Social.

\section{ABSTRACT}

This article aims to present a general mapping of participatory mechanisms for nonstate actors in international organizations. Forty institutions and international organizations were surveyed regarding the institutionalization of the participation of non-state actors. To achieve the proposed objective, we resorted to bibliographic review and documentary research. From the analysis, we were able to verify that the institutionalization of participatory mechanisms in the international arena dates back to the creation of the UN System. In addition, we concluded that $77 \%$ of the organizations surveyed have institutionalized mechanisms of social participation, and most of the participatory mechanisms offered to non-state actors are of and advisory and collaborative nature. We also concluded that most of the mechanisms created by international organizations that were researched date back to the late 1990s and early 2000s/2010s, and this phenomenon is closely related to the promotion of good governance standards, in the post-Cold War. 
Keywords: International Organizations; Participatory Mechanisms; Social Participation.

\section{INTRODUÇÃO}

A participação política de cidadãos comuns nos negócios públicos remonta à Ágora grega, um espaço de deliberação público onde os cidadãos discutiam questões de interesse público. Nesse período, as cidades-estados se constituíam enquanto centro das decisões políticas. Ainda que possam ser feitas críticas, como a exclusão de mulheres, escravos e imigrantes do processo político, é a partir desse cenário que se desenvolve todas as configurações e transformações democráticas do mundo moderno (Dahl, 2012).

Aristóteles, fundador da tradição republicana, salientava a necessidade da participação popular no governo, visto que esta seria essencial para o desenvolvimento e o exercício das virtudes humanas. Há um forte ideal normativo de que os cidadãos das polis deveriam ser virtuosos, justos e felizes, buscando sempre o bem comum. Havia também neste período uma ideia de que as democracias deveriam possuir tamanho reduzido, uma forma de facilitar a interação, o convívio e a assimilação dos desejos dos cidadãos (Dahl, 2012).

O aumento da complexidade social e a transformação das cidades-estados em Estados nacionais fizeram com que a participação pública direta se tornasse inviável. É a partir deste momento que surge a necessidade de delegação de responsabilidades políticas a um outrem, por meio da representação. Dessa forma, quanto maior a escala de um Estado nacional e quanto mais complexo em termos sociais, maior a dificuldade de que inúmeros e diversos interesses sejam contemplados (Dahl, 2012).

Num mundo cada vez mais interconectado e com identidades deslocadas, fragmentadas e descentralizadas (Hall, 2006), um grande problema político se coloca: como conciliar interesses e demandas tão diversas em um sistema representativo que seja minimamente satisfatório para grande parcela da população? Tal equacionamento é um problema eminentemente contemporâneo. Segundo Santos (1998), tal fenômeno representa o caráter conflitivo da dinâmica poliárquica, ou seja, o número de interesses desfavoravelmente afetados por decisões majoritárias é potencialmente superior ao 
número de interesses atendidos.

Este artigo tem como objetivo realizar um mapeamento geral de mecanismos participativos para atores não-estatais em organizações internacionais, elencando as possibilidades de participação e o ano de criação do mecanismo participativo. Com vistas a atingir este objetivo, recorremos à revisão bibliográfica e à pesquisa documental no website das organizações.

Diante disso, este artigo está dividido em duas seções. Na primeira, discorremos rapidamente sobre a crise dos instrumentos da democracia liberal e a proposta de aperfeiçoamento destas falhas, apresentando os argumentos da democracia participativa e deliberativa. Também, nesta seção, realizamos uma análise comparativa sobre a agenda de mecanismos participativos na Ciência Política e nas Relações Internacionais, discorrendo brevemente sobre a literatura sobre movimentos sociais, transnacionalismo e sociedade civil global. Na segunda seção, é realizado o mapeamento de experiências participativas em instituições e organizações internacionais. Por fim, realizamos as considerações finais.

\section{A CRISE DA DEMOCRACIA LIBERAL E A PROPOSTA DA DEMOCRACIA PARTICIPATIVA E DELIBERATIVA}

Há tempos que o modelo liberal de democracia se debruça cada vez mais sobre um terreno movediço, dando sinais que seus instrumentos típicos - tendo o período eleitoral como o momento ápice - já não são mais suficientes para representar interesses de uma sociedade cada vez mais complexa e fragmentada. Os sinais são visíveis mundo afora. Em 2019, protestos em massa demonstrando o descontentamento frente às políticas dos governos nacionais aconteceram no mundo todo: Bolívia, Chile, Colômbia, Equador, Haiti, Venezuela, Hong Kong, Reino Unido, Espanha, França, Líbano, Iraque, entre outros. Dados do Democracy Index 2019 mostram uma piora na confiança dos cidadãos em seus governos nacionais $(4,81)$, em uma escala que vai até 10 . Além dos dados produzidos pela The Economist Intelligence Unit, há outras organizações que organizam dados sobre a questão democrática, como o Dalia Research, Freedom House, Varieties of Democracy. 
Os relatórios anuais do Democracy Index produzidos pela The Economist Intelligence Unit, mostram um cenário abrangente e geral sobre a situação democrática no mundo todo. Estes dados são colhidos e organizados desde 2006, o que permite uma melhor análise comparativa com anos precedentes. Para além disto, possibilita uma análise por região geográfica e por variável (liberdades civis, cultura política, participação política, funcionamento do governo e processo eleitoral e pluralismo). Ainda que os dados estatísticos por si só não sejam suficientes para realizarem inferências e conclusões aprofundadas, eles oferecem uma boa visão sobre a situação democrática mundo afora. Os dados são apresentados seguidamente com uma narrativa que tenta explicar a melhora, estabilidade ou piora de cada variável explicativa. Para além disso, os relatórios anuais trazem de forma pormenorizada os elementos que foram considerados em cada variável. A debilidade destes relatórios é que eles não permitem conclusões mais aprofundadas sobre casos específicos. Dessa forma, os dados somente - ou deveriam - ser utilizados como um subsídio para uma análise mais rigorosa, combinado com métodos analíticos complementares.

Na mesma linha, o Varieties of Democracy (V-Dem), oferece relatórios e análises gerais sobre a situação da democracia no mundo todo. Interesse notar, diferentemente das outras organizações, esta inclui o componente igualitário como uma variável a ser analisada nas democracias (V-Dem Institute, 2020). Esta variável visa mensurar em que medida os grupos sociais de uma determinada sociedade gozam de capacidades iguais para participar na arena política. Para além dos relatórios, a organização conta com uma base de dados sofisticada, composta por índices sociais, econômicos e políticos de diversos países, que podem ser visualizados em um amplo espaço temporal. É uma ferramenta riquíssima para pesquisadores das mais diversas áreas. De outro lado, o Freedom House, para além de uma visão generalista sobre a situação democrática mundo afora, oferece análises detidas sobre diversos países. No entanto, tais análises aprofundadas tendem a se limitar ao continente europeu, como exemplificado em um dos últimos relatórios lançados "Nations in transition 2020: dropping the democratic facade" (Freedom house, 2020). 
Enquanto alguns autores argumentam que a democracia está em crise, visto que não mais atenderia aos interesses cada vez mais complexos e fragmentados da sociedade moderna, outros autores da teoria política democrática argumentam haver apenas uma crise de representação. As razões apresentadas giram em torno dos seguintes argumentos: uma autonomização dos parlamentares e dos partidos políticos durante o exercício do mandato com a consequente desconsideração da opinião do eleitor; a perda da relação de confiança entre o parlamento e o cidadão; o domínio de grupos economicamente mais poderosos com uma estrutura de lobby mais organizada sobre os parlamentares; o descompromisso com o ordenamento jurídico e a falta de qualidade legislativa na elaboração das leis; a incapacidade do parlamento em responder às demandas cada vez mais complexas e variadas da sociedade; a falta de ética de parlamentares que utilizam os recursos institucionais para o exercício do mandato de forma irregular (Faria, 2011).

Apesar de todas essas debilidades das democracias contemporâneas, os teóricos democráticos salientam a importância de regimes democráticos como salvaguarda para a proteção dos direitos humanos, da autodeterminação individual e coletiva e do Estado democrático de direito. No mundo todo, grupos autoritários; a volatilidade da economia nos países em desenvolvimento; a questão do respeito aos direitos humanos das minorias; a crise da democracia representativa parece estar entre as muitas questões que continuamente tencionam a democracia.

Tendo em vista a existência de inúmeras debilidades no sistema democrático liberal tradicional, que já como dissemos, tende a limitar a participação popular ao período meramente eleitoral, começam a surgir correntes teóricas contestatórias complementares a esse sistema: a teoria democrática participativa e a teoria democrática deliberativa.

A teoria democrática participativa - que possui alguns trabalhos clássicos (Pateman, 1992; Manin, 1997; Barber, 1984) - emerge nas décadas de 1960 e 1970 propondo um aperfeiçoamento do sistema representativo, ao acreditar que a política deveria ser feita mais "próxima das pessoas" (Miguel, 2005). Um argumento básico apresentado dentro dessa corrente teórica é que a limitação da participação popular, 
exclusivamente em períodos eleitorais, gera um déficit democrático ao permitir uma autonomização dos representantes políticos frente às vontades políticas dos que dizem representar. Além do mais, a complexidade do mundo moderno fez com que as inúmeras e contraditórias demandas dos cidadãos não se fizessem escutadas e representadas nas instâncias políticas devidas. Em suma, se cria um vácuo de representação quando a participação popular é limitada somente ao voto, tornando os representantes políticos unaccountable. Dessa forma, a teoria democrática participativa salienta a necessidade da criação de arranjos institucionais - para além dos períodos eleitorais - que permitam uma maior participação dos cidadãos comuns nos negócios públicos. É importante ressaltar, mais uma vez, que tal teoria, ainda que não poupe críticas ao modelo liberal tradicional, não propõe uma superação deste, mas sim um aprimoramento.

De acordo com Della Porta (2013), os teóricos da democracia participativa rendem críticas aos autores democráticos liberais, visto que os últimos não seriam realistas ao tratar os cidadãos como livres e iguais, enfatizando as assimetrias de poder existentes que uma igualdade meramente legal não conseguiria resolver. Dessa forma, para combater as desigualdades e seus efeitos nefastos, a participação popular deveria ser contínua e direta, como uma forma de aumentar o protagonismo dos cidadãos e a transparência das decisões estatais.

Barber (1984) desenvolve o conceito de 'democracia forte', se referindo a um modelo participativo de democracia. Tal modelo seria baseado na ideia de uma sociedade autogovernada de cidadãos que são unidos primordialmente pela educação cívica. O autor desenvolve este conceito em oposição ao que ele chama de 'fina democracia', em outras palavras, a democracia liberal, representativa. No entanto, o autor ressalta que o argumento desenvolvido por ele é mais complementar do que radical ao argumento democrático liberal.

Fica claro, a partir do exposto acima, a relevância da participação pública nos negócios públicos como uma fonte de aprendizado social comunitário, do compartilhamento de visões, valores e ideias para a construção de uma comunidade 
política 'minimamente' harmônica, ainda que no plano normativo. Pensamento este que converge com os autores do republicanismo cívico.

Creighton (2005) define a participação pública como o processo no qual as preocupações, necessidades e valores sociais são incorporados nas tomadas de decisões governamentais. Para este autor, a participação pública é um contínuo que se desenvolve em quatro processos. A primeira etapa se constitui numa via de mão única, na qual os agentes governamentais prestam informações ao público para que estes consigam participar ativamente da vida pública. A segunda etapa é o momento no qual se escuta o público, por meio de assembleias, consultas públicas. Já na terceira etapa, os agentes governamentais se engajam na resolução de problemas que foram levantados pelo público. No último passo, há o desenvolvimento de acordos.

O autor ainda lista oito benefícios que a participação pública de cidadãos comuns pode trazer para a vida pública, entre estes estão: a melhora da qualidade das decisões, a minimização do custo e do delay político (decisões unilaterais são sempre mais rápidas, mas custosas politicamente para serem implementadas, visto que frequentemente há muita resistência); construção de consenso, possibilitando o entendimento entre as partes divergentes, reduzindo a controvérsia política e conferindo legitimidade para as decisões governamentais; aumenta a facilidade de implementação; evita casos de confrontos políticos violentos - no entanto, o autor reconhece que a participação pública não irá, necessariamente, reduzir ou eliminar todos os conflitos. O sexto benefício se refere à manutenção da credibilidade e legitimidade das decisões governamentais quando estas são tomadas em acordo ao público a que se dirige; a participação pública também antecipa preocupações e atitudes públicas e, por fim, permite o desenvolvimento da sociedade civil, os tornando melhor informados e educados em termos políticos.

Apesar das inúmeras benesses, há que se ressaltar as distorções que propiciam efeitos negativos da participação social. Entre estes, podemos destacar de que nem sempre as discussões são de fato pautadas pelo bem comum, ou seja, há inúmeros interesses privados secundários que estão em voga nas discussões públicas, o que muitas vezes se deve pelo fato da categoria 'sociedade civil' abranger inúmeros 
segmentos, com interesses e demandas divergentes, que vão desde associações comunitárias de bairros até sindicatos e empresas. Outra questão importante a ser problematizada diz respeito ao grau de inclusão desses espaços institucionalizados de participação social. Em outras palavras, qual é o perfil das pessoas que participam nestes espaços públicos? Há diversidade, em termos de classe, raça, gênero, ocupação?

Indo mais adiante na teoria política, os autores da democracia deliberativa salientam a necessidade da construção de espaços institucionais dialógicos e da formação de consensos em torno das decisões públicas que devem ser tomadas. Dessa forma, os cidadãos, ainda que em termos ideacionais, devem participar ativamente de um debate 'acalorado' onde se troca argumentos e contra-argumentos em relação a questões que afligem a coletividade, e deve-se chegar a um consenso em torno dessas questões (Habermas, 2003; Gutmann; Thompson, 2004; Young, 2000; Dryzek, 2002).

Segundo Gutmann e Thompson (2004), o objetivo principal da democracia deliberativa é providenciar uma concepção para lidar com os desacordos morais na política. Ainda segundo os autores, os propósitos da democracia deliberativa são: a promoção de legitimidade das decisões coletivas, respondendo a uma das fontes de desacordo moral, a escassez de recursos, que tornam as difíceis escolhas dos políticos mais aceitáveis; o encorajamento do espírito público das diferentes perspectivas nos resultados públicos, respondendo a outra fonte de desacordo moral: a generosidade limitada. Dessa forma, o estímulo ao espírito público nas decisões coletivas, tornaria os indivíduos mais altruístas. Outro propósito da democracia deliberativa é promover o respeito mútuo nos processos decisórios, respondendo à outra fonte de desacordo moral: os valores morais incompatíveis entre os indivíduos, assim sendo, a deliberação consegue ajudar os participantes a reconhecer o mérito que seus oponentes reivindicam em cada proferimento. A democracia deliberativa ajuda também a corrigir erros, respondendo à outra fonte de desacordo moral: o entendimento incompleto. Portanto, os fóruns de deliberação providenciam uma oportunidade para avançar no entendimento individual e coletivo, sendo que, nesses espaços de negociação, os cidadãos conseguem melhor visualizar o que eles querem. 
Na Ciência Política, há uma vasta agenda de pesquisa em torno da participação de atores não-estatais. O Brasil é considerado um país inovador e referência quando o assunto é este. Não à toa, a Ciência Política brasileira possui inúmeros estudos sobre este tema desde a redemocratização, com um significativo avanço sobre diversos métodos para se estudar todas as nuances que envolvem esta questão (Avritzer, 2006; 2008 Dagnino, 2002; Dagnino; Tatagiba, 2007; Lavalle et al., 2006).

Em termos comparativos com a Ciência Política, podemos perceber que os estudos sobre participação de atores não-estatais em arenas, instituições e organizações internacionais tendem a serem menos focados na elaboração de métodos para o estudo da participação social, por exemplo. Isso se deve, talvez, pela complexidade do estudo deste tema quando levado à arena internacional. Há uma multiplicação acentuada dos atores e acordos envolvidos.

Almeida (2009), por exemplo, ao estudar a participação social em conselhos municipais de saúde, argumenta que o número de falas durante as deliberações públicas se constitui em uma variável importante a ser analisada, visto que quanto maior o nível de discussão antes do momento que precede o voto, mais se aproxima do ideal deliberativo de interatividade e pluralidade de discurso. Além disso, a autora acredita ser relevante investigar se as falas dos participantes expressam denúncias ou demandas, podendo se inferir, a partir disso, se o conselho é mais propositivo ou reativo em sua atuação.

Uma ferramenta interessante para pesquisadores que se debruçam a entender a questão participativa no cenário brasileiro e latino-americano é o Latinno, uma base de dados sobre as inovações democráticas que estão em curso na América Latina, desde os anos 1990. A base de dados apresenta inúmeras inovações democráticas, elencando seu desenho institucional (tipo de formalização, frequência, seleção e tipos de participantes, capacidade de tomada de decisões), as formas de participação (eparticipação, deliberação, voto direto, representação cidadã) e os fins visados por cada mecanismo participativo (inclusão política, accountability, Estado de direito). É também uma ferramenta valiosa para pesquisadores da área, que permite visualizar variáveis desagregadas, em espaços geográficos e no tempo (1990-2016) (Pogrebinschi, 2017). 
Nas Relações Internacionais, estudos empíricos sobre a participação de atores nãoestatais em arenas, instituições e organizações internacionais ainda se mostra relativamente incipiente. Parte significativa dos trabalhos encontrados durante a pesquisa focam no Sistema ONU (Menezes, 2010; Ruhlman, 2015; Mckeon, 2009) e no Mercosul (Budini, 2015; Serbin, 2013; Ramanzini Júnior; Farias, 2014). Há ainda alguns estudos sobre a participação da sociedade civil na SADC (Matlosa; Lotshwao, 2006); na ASEAN (Quayle, 2012; Hsien-li, 2011) e na América Central (Carrillo, 2013).

Ruhlman (2015), ao estudar as possibilidades de interação entre o Sistema ONU e a sociedade civil, se questiona por que atores não-estatais adquirem direitos de participação em organizações internacionais. Segundo o argumento da autora, as organizações intergovernamentais e Estados que as compõem, ao garantirem direitos de participação à atores não-estatais, estão apenas perseguindo seus interesses. A autora ainda realiza uma importante distinção entre as formas de participação e colaboração dos atores não-estatais com as organizações internacionais. A autora entende a participação de atores não-estatais em organizações internacionais como 'níveis' que podem ou não ser implementados. De um lado, há o que a autora designa como 'downstream engagement', que é a colaboração ou parceria dos atores nãoestatais. Por outro lado, em um nível levemente mais elevado de abertura à sociedade civil há o que a autora designa como 'upstream engagement', que são consultas feitas a respeito da governança geral ou do gerenciamento da organização. O 'upstream engagement' leva a um estágio superior de participação, o que a autora denomina de transparência e acesso, que são a exposição de documentos da organização internacional com os atores não-estatais ou a permissão de que grupos observem o processo de governança. No último nível - o conceito de participação - é entendido como a oportunidade formal de fazer parte do processo de atuação da organização, onde há um compartilhamento de informações com os decision-makers. No entanto, a autora, ressalta, tal nível não é necessariamente uma oportunidade para votar nas decisões políticas da organização.

Segundo Ruhlman (2015), as conferências globais tiveram importância substancial para a atuação de ONGs e sociedade civil. A conferência de Estocolmo em 1972 e a 
Conferência da ONU sobre Meio Ambiente e Desenvolvimento em 1992 foram fundamentais para aumentar a inclusão das ONGs e depois a participação no "universo" da ONU:

At the very same time, the UN is a state-based organization and there is persistent member resistance to significant formal participation of NSAs. Such opposition is not universal, and arguably is led by a minority of governments that are especially hostile to the idea of institutionalized participation for NGOs, but democracies that are generally supportive of civil society inclusion have also expressed opposition to extensions of their formal participation in the UN (Ruhlman, p. 37, 2015).

Também estudando as interações entre o Sistema ONU e a sociedade civil, Menezes (2010) lista as atividades que os atores não-estatais podem desenvolver na ONU. Entre estes estão: (i) o diálogo político, por meio da participação formal ou informal nas deliberações intergovernamentais; (ii) advocacy, que é a cooperação com vistas a despertar a atenção pública; (iii) a mobilização de fundos privados para a captação de programas e projetos da ONU; (iv) difusão de conhecimento e expertise; (v) operacional, por meio da colaboração no desenvolvimento, implementação e avaliação de programas e projetos; (vi) promoção de parcerias.

Apesar da constatação da incipiência de estudos empíricos nas Relações Internacionais, no que tange à participação social, podemos identificar um grande debate teórico acerca da emergência e do desenvolvimento dos atores não-estatais na política internacional. A literatura sobre movimentos sociais nas Ciências Sociais pode ser considerada o "berço" do adensamento teórico que se desenvolveu posteriormente nas Relações Internacionais, por meio da literatura do transnacionalismo e da sociedade civil global.

Inicialmente, os estudos sobre os movimentos sociais não analisavam as nuances do relacionamento entre a atuação destes movimentos no âmbito doméstico e internacional, algo que começa a sofrer alterações a partir da emergência do ativismo transnacional, nos anos 1960 e 1970. A teoria da Abordagem do Processo Político ou das Oportunidades Políticas, desenvolvidas a partir dos trabalhos de Tarrow (2005) e Della Porta e Tarrow (2005), é a que mais se destaca dentro desta literatura. De acordo com esta teoria, a estrutura de interação entre Estados, instituições internacionais e atores não-estatais produziriam oportunidades políticas para que os atores não-estatais 
se engajassem cada vez mais na política internacional. No entanto, a teoria reconhece que a disputa política transnacional é travada não somente por meio de oportunidades, mas também por ameaças.

Posteriormente, a partir da abertura do campo à análise transnacional, uma vasta bibliografia discorre sobre a atuação, táticas e mobilizações de redes de comunidades epistêmicas, redes de advocacy, da difusão de normas internacionais e sobre governança global (Karns; Mingst, 2010; Lemke, 2006; Oliveira, 2016; Towns; Rumelili, 2017; Löblová, 2017; Bache; Flinders, 2004; Rosenau, 2004; Bülow, 2010; Colás, 2002). Nessa vertente, o trabalho de Keohane e Nye (1977) é considerado pioneiro. No entanto, a Teoria da Interdependência Complexa é criticada por se centrar nas corporações multinacionais - na tradição da economia política internacional - deixando às margens a discussão sobre organizações não-governamentais internacionais, por exemplo (Della Porta; Tarrow, 2005). De acordo com o argumento de Budini (2015), a agenda de pesquisas deste período pouco avançou porque foram estabelecidas dicotomias entre abordagens focadas no Estados e abordagens focadas na sociedade. No entanto, o avanço desta área de estudos foi retomado na década de 1990, quando novos autores começam a situar seus trabalhos em uma onda Construtivista (RisseKapen, 1995; Sikkink, 1993; Keck; Sikkink, 1998).

Outra frente de literatura importante que discute sobre atores não-estatais na política internacional é a sobre sociedade civil global. Em comparação com as outras frentes de literatura anteriormente citada, é a mais densa e controversa nas Relações Internacionais. As principais controvérsias giram em torno da existência ou não desta sociedade civil global; do caráter positivo e negativo que esta pode desempenhar na política internacional e discussões sobre conceituações, que incluem quais atores estariam inseridos dentro desta ampla categoria. Kaldor (2003) argumenta que não existiria apenas uma sociedade civil, mas muitas, que exerceriam influência sobre diversos assuntos de relevância transnacional, como os direitos humanos, meio ambiente, entre outros.

Lipschutz (1992) argumenta que a emergência da sociedade civil pode ser explicada por um fenômeno interativo, ao nível estrutural e ao nível micro. Ao nível estrutural, o 
autor acredita que o princípio organizador do sistema internacional, a anarquia, estaria "enfraquecida". Tal mudança não seria apenas resultados das mudanças no cenário internacional após o final da Guerra Fria, mas também por uma crescente aceitação do liberalismo. Para além dessas questões, a questão da disponibilidade de mais recursos militares pelos Estados, teria provocado um maior "adensamento" das relações políticas globais. Na argumentação do autor, todo este cenário teria propiciado espaços políticos para que atores não-estatais criassem alianças e redes ao redor do mundo. Do nível micro ou da agência, os governos nacionais passaram cada vez mais a serem incapazes de oferecer serviços de bem-estar demandados por cidadãos cada vez mais conscientes de seus interesses. Dessa forma, os cidadãos buscaram suprir suas necessidades a partir de novas maneiras, sendo que os conhecimentos e técnicas utilizadas começam a ser replicadas mundo afora, pela facilidade dos meios de comunicação e de transporte.

Scholte (2002) questiona quais seriam as implicações da mobilização da sociedade civil para a democracia na governança global. No entendimento do autor, a sociedade civil seria composta por inúmeros e díspares atores e organizações, que iriam desde aqueles dispostos a buscar mudanças radicais na política internacional até atores reformistas, que buscariam apenas tímidas acomodações de normas e regras sociais já acordadas. No que tange aos aspectos positivos desempenhados pela sociedade civil global, o autor reconhece que esta poderia dar voz aos atores sociais marginalizados do centro político e que a sociedade civil global poderia produzir um aumento da accountability das organizações públicas. De outro lado, o autor reconhece que a sociedade civil global pode não perseguir fins democráticos, como por exemplo, grupos ultranacionalistas e racistas.

Dentro da literatura sobre sociedade civil global há também discussões sobre a dimensão ética e moral da sociedade civil global; sobre a constituição de arranjos cosmopolitas e da cidadania global, bem como sobre o potencial emancipatório da sociedade civil global (Habermas, 2001; 2012; Linklater, 1998; Cox, 1999; Kant, 1995). Kant em "À paz perpétua" (1995), publicado pela primeira vez em 1795, realiza um dos primeiros ensaios discutindo acerca de uma possível constituição futura de um 'direito 
cosmopolita'. De acordo com o argumento do autor, o direito de visita seria um direito de todos. Dessa forma, ninguém poderia ser tratado de forma hostil.

Já Linklater (1998) defende o desacoplamento entre a ideia de cidadania e soberania, atrelada aos Estados nacionais. Isso porque existiria uma tensão contemporânea na ideia de cidadania, visto que esta significaria simultaneamente inclusão e exclusão. Inclusão para aqueles que possuem cidadania em um Estado nacional, onde usufruem de direitos e cumprem com obrigações. Exclusão porque no momento em que este cidadão parte para outros Estados, perde todos os seus direitos adquiridos. Segundo o autor, este desacoplamento permitiria a criação de um senso moral de responsabilidade diante de todos os grupos vulneráveis do mundo, como por exemplo, os refugiados.

\section{MECANISMOS DE PARTICIPAÇÃO SOCIAL NAS ORGANIZAÇÕES INTERNACIONAIS}

A compreensão sobre participação social neste artigo converge com o pensamento de Ruhlman (2015), que entende a participação como uma oportunidade formal de fazer parte do processo de operação de uma organização internacional. É importante ressaltar, que tal participação não inclui necessariamente o direito ao voto nas decisões. Dessa forma, a participação social é a atuação de organizações, grupos e indivíduos que não representam Estados nacionais. Dito de outra maneira, são todos os atores nãogovernamentais ou não-estatais.

A institucionalização da participação social no cenário internacional, seja em termos normativos ou concretos, remonta à criação do sistema ONU. Segundo Ruhlman (2015), as ONGs foram ativas no momento de constituição da ONU e a Carta da ONU reconhece formalmente as ONGs em seu artigo 71, permitindo que o ECOSOC forme arranjos de consultas às ONGs:

The Economic and Social Council may make suitable arrangements for consultation with non-governmental organizations which are concerned with matters within its competence. Such arrangements may be made with international organizations and, where appropriate, with national organizations after consultation with the Member of the United Nations concerned (United Nations, 1945). 
Pensando na institucionalização de mecanismos participativos na esfera internacional, o Conselho Econômico e Social das Nações Unidas (ECOSOC) pode ser considerado pioneiro. Sua primeira Resolução sobre o tema data de 1950, Resolução 288 B (X). A última resolução sobre o tema é a 1996/31. Esta reconhece a diversidade e a importância desempenhada pelas ONGs no auxílio aos trabalhos da organização intergovernamental e dispõe sobre as relações consultivas estabelecidas entre a ECOSOC e seus órgãos subsidiários e as ONGs.

Esta Resolução realiza uma importante distinção entre a participação sem voto, garantida a Estados não membros e agências especializadas e a participação com status consultivo, garantido às ONGs. Os 'tipos' de status consultivo garantido às ONGs se dividem em três tipos: geral, especial e de lista "Roster". O status consultivo geral é concedido às ONGs que trabalham com assuntos econômicos e sociais, e que são representativas de grandes segmentos da sociedade, atuando em inúmeros Estados. Já o status consultivo especial é provido às ONGs que possuem competências específicas dentro do leque de temas coberto pela ECOSOC e seus corpos subsidiários. O último tipo de status consultivo, o de lista ou Roster é dado às ONGs que desejam realizar contribuições episódicas (Ecosoc, 1996).

Além disso, vale destacar alguns dos direitos conferidos às ONGs que gozam de status consultivo geral e especial. Entre estes estão a possibilidade de designar autoridades representativas a serem observadores em encontros públicos promovidos pelo ECOSOC; de fazerem declarações escritas, desde que observadas as regras, e a possibilidade de fazerem apresentações orais, desde que aprovada pelo comitê das ONGs, que ainda determina sob quais temas se pode discursar (Ecosoc, 1996).

Apesar de inovadora, segundo Ruhlman (2015), a Resolução 1996/31 do ECOSOC falha ao definir o que é uma ONG, utilizando linguagem ambígua, que segundo ela, estaria relacionado com um desacordo entre os Estados-membros sobre a participação de atores não-estatais e sobre a extensão em que se deveria dar esta participação. De fato, podemos perceber uma definição muito ampla e pouco conceitual: "the term 'organization' shall refer to non-governamental organizations at the national, subregional, regional or international levels" (Ecosoc, 1996). 
Outra medida implementada no Sistema ONU que vale a pena destacar é a criação da Non-governamental Liaison Service, uma agência que desde a década de 1980 propiciou uma articulação mais efetiva entre os atores não-estatais e o sistema ONU. Em conferência realizada em 1995, os membros desta agência reconheceram a necessidade de uma governança global, como resposta aos efeitos da globalização e ao declínio da influência da ONU, demandando uma reforma da ONU, com vistas à sua democratização, elencando a necessidade de transparência das decisões, accountability, menos burocracia e maior controle por parte da sociedade civil global (Teixeira, 2001).

A participação social no sistema ONU foi impulsionada na década de 1990 a partir da realização de diversas conferências internacionais, a ECO-92, no Rio de Janeiro; a conferência sobre direitos humanos em Viena (1993); sobre população, no Cairo (1994); sobre mulheres em Pequim (1995); sobre desenvolvimento social em Copenhagen (1995); sobre alimentos em Roma (1996) e a conferência sobre o Tribunal Penal Internacional (1998), também em Roma. De acordo com Paul (2012), tais conferências atraíram inúmeras organizações da sociedade civil e ativistas porque elas viram este espaço como alternativo e mais democrático, quando comparado com as instituições de Bretton Woods (Banco Mundial e Fundo Monetário Internacional). Em cada conferência, comitês preparatórios intergovernamentais contaram com a presença de ONGs e ativistas sociais.

No argumento de Mckeon (2009), o sistema ONU abriu importantes espaços para a participação da sociedade civil na década de 1990, principalmente durante as conferências internacionais. No entanto, a organização falhou em passar de uma fase com participações mais genéricas e episódicas para uma incorporação significativa destes atores no processo político global. De acordo com a autora, as bases para tal incorporação estariam muito mais sólidas do que nos anos 1990, principalmente quanto às capacidades estruturais de atuação das organizações da sociedade civil, como a facilidade de comunicação por meio das mídias digitais. Não obstante, a incorporação dos atores não-estatais em organizações internacionais, como o Sistema ONU sofre 
com a desconfiança ou tentativas de impedimento por parte de muitos países, que colocam seus interesses nacionais em primazia.

Um ponto que merece destaque é a diferença entre a existência formal de canais de participação e a participação efetiva dos atores não-estatais, ligado principalmente ao empoderamento e a influência destes no decision-making das organizações internacionais em que participam. Em outras palavras, este debate trata da qualidade da participação dos atores não-estatais. Os atores sociais sentem que as suas demandas são consideradas nas decisões das organizações em que participam? As assimetrias entre os agentes governamentais e os atores não-estatais repercute de que forma na dinâmica participativa? Há também que se considerar a questão do preparo dos atores não-estatais diante de assuntos técnicos, que nem sempre dominam, frente à exiguidade de disponibilidade de tempo. Igualmente, a possibilidade de cooptação e sufocamento dos atores sociais pelos agentes governamentais é objeto que deve ser levado em conta. Estas e outras questões devem ser analisadas caso a caso, por meio de entrevistas e outros recursos ao alcance do pesquisador, para que se possam ser feitas inferências.

Um exemplo destas questões citadas é a participação social na Associação de Nações do Sudeste Asiático (ASEAN). Apesar de existirem mecanismos formais de input para a sociedade civil, inúmeros autores tendem a salientar a dificuldade da participação social nas esferas regionais, dado que o caráter soberanista e o princípio da não-interferência nos assuntos domésticos continuam como traços característicos da organização regional, algo designado pela literatura como 'ASEAN way' (Acharya, 1997; Haacke, 1999). Ao estudar a participação social na Comissão Intergovernamental de Direitos Humanos da ASEAN, Asplund (2014) chega à conclusão de que as organizações da sociedade civil atuam em um ambiente "altamente não amigável", visto que os membros mais autoritários da ASEAN tendem a limitar o envolvimento da sociedade civil, usando ou ameaçando utilizar o princípio do consenso nas tomadas de decisões.

Abaixo, em forma de tabela, organizo outros mecanismos participativos implementados por organizações, instituições e agências internacionais: 
TABELA 1 - Mecanismos participativos em organizações e instituições internacionais

\begin{tabular}{|c|c|c|c|c|}
\hline Ol & $\begin{array}{l}\text { Área } \\
\text { geográfica }\end{array}$ & $\begin{array}{l}\text { Ano de } \\
\text { criação da Ol }\end{array}$ & $\begin{array}{l}\text { Ano criação } \\
\text { mecanismo } \\
\text { participativo }\end{array}$ & $\begin{array}{l}\text { Formas de } \\
\text { participação }\end{array}$ \\
\hline $\begin{array}{l}\text { Comissão } \\
\text { Interamericana de } \\
\text { Direitos Humanos }\end{array}$ & América & 1959 & $1965^{2}$ & Petições \\
\hline $\begin{array}{l}\text { Sistema de } \\
\text { Integração Centro- } \\
\text { americana }\end{array}$ & América & 1991 & 1993 & $\begin{array}{l}\text { Direito à voz e } \\
\text { participação nas } \\
\text { decisões do Comitê } \\
\text { Consultivo } \\
\text { (CCSICA) }\end{array}$ \\
\hline Mercosul & América & 1991 & 1996 & $\begin{array}{l}\text { Participação nas } \\
\text { Cúpulas Sociais; } \\
\text { consultas; troca de } \\
\text { informações }\end{array}$ \\
\hline $\begin{array}{l}\text { Comunidade } \\
\text { Andina }\end{array}$ & América & 1969 & 1998 & $\begin{array}{l}\text { Participação em } \\
\text { mesas e instâncias } \\
\text { temáticas }\end{array}$ \\
\hline $\begin{array}{l}\text { Organização dos } \\
\text { Estados } \\
\text { Americanos }\end{array}$ & América & 1948 & 1999 & $\begin{array}{l}\text { Assistir atividades, } \\
\text { realizar } \\
\text { apresentações, } \\
\text { levar informações } \\
\text { e prestar } \\
\text { assessoria }\end{array}$ \\
\hline $\begin{array}{l}\text { Banco Internacional } \\
\text { de } \\
\text { Desenvolvimento }\end{array}$ & América & 1959 & $2000^{3}$ & $\begin{array}{l}\text { Informação, } \\
\text { diálogos, consultas } \\
\text { públicas, }\end{array}$ \\
\hline
\end{tabular}

\footnotetext{
${ }^{2}$ Fonte: Ramanzini (2014)

${ }^{3}$ Fonte: Rodrigues; Maciel (2014)
} 


\begin{tabular}{|c|c|c|c|c|}
\hline & & & & $\begin{array}{l}\text { colaboração e } \\
\text { alianças. }\end{array}$ \\
\hline UNASUL & América & 2007 & 2012 & $\begin{array}{l}\text { Direito à voz em } \\
\text { sessões do órgão e } \\
\text { demais instâncias; } \\
\text { apresentação de } \\
\text { recomendações e } \\
\text { status consultivo }^{4}\end{array}$ \\
\hline $\begin{array}{ll}\text { Comissão } & \text { Africana } \\
\text { dos } & \text { Direitos } \\
\text { Humanos } & \text { e dos } \\
\text { Povos } & \end{array}$ & África & 1987 & 1988 & $\begin{array}{l}\text { Status de } \\
\text { observador; } \\
\text { apresentação de } \\
\text { comunicações } \\
\text { escritas sobre } \\
\text { violação de DH }\end{array}$ \\
\hline $\begin{array}{l}\text { Comunidade para o } \\
\text { Desenvolvimento } \\
\text { da África Austral }\end{array}$ & África & 1992 & 1998 & $\begin{array}{l}\text { Encontros } \\
\text { interativos e status } \\
\text { de observador }\end{array}$ \\
\hline $\begin{array}{l}\text { Banco Africano de } \\
\text { Desenvolvimento }\end{array}$ & África & 1964 & 1999 & $\begin{array}{l}\text { Diálogo, revisão de } \\
\text { gastos públicos; } \\
\text { consultas }\end{array}$ \\
\hline $\begin{array}{l}\text { Comunidade } \\
\text { Econômica dos } \\
\text { Estados da África } \\
\text { Ocidental }\end{array}$ & África & 1975 & 2003 & $\begin{array}{l}\text { Diálogo e parcerias } \\
\text { por meio da } \\
\text { WACSOF }\end{array}$ \\
\hline União Africana & África & 1999 & 2004 & $\begin{array}{l}\text { Fóruns interativos } \\
\text { e consultas }\end{array}$ \\
\hline $\begin{array}{l}\text { Mercado Comum } \\
\text { da África Oriental e }\end{array}$ & África & 1994 & 2004 & Direito consultivo $^{5}$ \\
\hline
\end{tabular}

\footnotetext{
${ }^{4}$ Fonte: Aguilar (2017)

${ }^{5}$ Fonte: Moyo (2007)
} 


\begin{tabular}{|c|c|c|c|c|}
\hline Austral & & & & \\
\hline $\begin{array}{l}\text { Comunidade } \quad d a \\
\text { África Oriental }\end{array}$ & África & 1999 & 2012 & Diálogo; consulta \\
\hline ASEAN & Ásia & 1967 & 1979 & $\begin{array}{l}\text { 'Afiliação'(1979); } \\
\text { consultas } \\
\text { participação em } \\
\text { fóruns anuais } \\
\text { (2005) }\end{array}$ \\
\hline $\begin{array}{l}\text { Banco Asiático de } \\
\text { Desenvolvimento }\end{array}$ & Ásia & 1966 & 1987 & $\begin{array}{l}\text { Troca de } \\
\text { informações; } \\
\text { colaboração; } \\
\text { monitoramento de } \\
\text { projetos }\end{array}$ \\
\hline $\begin{array}{l}\text { Comissão } \\
\text { Intergovernamental } \\
\text { de Direitos } \\
\text { Humanos /ASEAN }\end{array}$ & Ásia & 2009 & 2015 & Status consultivo \\
\hline $\begin{array}{l}\text { Banco Europeu } \\
\text { para } \\
\text { Reconstrução e o } \\
\text { Desenvolvimento }\end{array}$ & Europa/Ásia & 1991 & 2000 & $\begin{array}{l}\text { Diálogo público; } \\
\text { consulta; pedido } \\
\text { de informações }\end{array}$ \\
\hline União Europeia & Europa & 1993 & 2002 & Diálogo; consulta \\
\hline UNICEF & Global & 1946 & 1952 & $\begin{array}{l}\text { Colaboração; } \\
\text { parcerias }\end{array}$ \\
\hline $\begin{array}{l}\text { Organização } \\
\text { Internacional do } \\
\text { Trabalho }\end{array}$ & Global & 1919 & 1956 & $\begin{array}{l}\text { Cooperação e } \\
\text { consulta }\end{array}$ \\
\hline Banco Mundial & Global & 1944 & 1981 & $\begin{array}{l}\text { Diálogo; consulta; } \\
\text { parcerias } \\
\text { institucionais e }\end{array}$ \\
\hline
\end{tabular}




\begin{tabular}{|c|c|c|c|c|}
\hline & & & & $\begin{array}{l}\text { compartilhamento } \\
\text { de informações }\end{array}$ \\
\hline $\begin{array}{l}\text { Programa das } \\
\text { Nações Unidas para } \\
\text { o Meio Ambiente }\end{array}$ & Global & 1972 & 1992 & $\begin{array}{l}\text { Diálogo; status } \\
\text { consultivo }\end{array}$ \\
\hline $\begin{array}{l}\text { Programa Mundial } \\
\text { de Alimentos das } \\
\text { Nações Unidas }\end{array}$ & Global & 1961 & 1995 & Colaboração \\
\hline $\begin{array}{l}\text { Organização das } \\
\text { Nações Unidas para } \\
\text { Alimentação } \\
\text { Agricultura }\end{array}$ & Global & 1945 & 1999 & $\begin{array}{l}\text { Status de } \\
\text { observador; status } \\
\text { consultivo; status } \\
\text { consultivo } \\
\text { especializado }\end{array}$ \\
\hline PNUD & Global & 1966 & 2001 & $\begin{array}{l}\text { Consulta; } \\
\text { colaboração }\end{array}$ \\
\hline $\begin{array}{l}\text { Fundo Monetário } \\
\text { Internacional }\end{array}$ & Global & 1945 & 2003 & Consultas \\
\hline ONU Habitat & Global & 2002 & 2009 & $\begin{array}{l}\text { Diálogo; status } \\
\text { consultivo }\end{array}$ \\
\hline $\begin{array}{l}\text { Organização para a } \\
\text { Proibição de Armas } \\
\text { Químicas }\end{array}$ & Global & 1997 & 2009 & $\begin{array}{l}\text { Participação em } \\
\text { fóruns anuais }\end{array}$ \\
\hline $\begin{array}{ll}\text { Fundo } & \text { de } \\
\text { População das } & \text { Nações Unidas }\end{array}$ & Global & 1969 & 2010 & $\begin{array}{l}\text { Diálogo por meio } \\
\text { da Civil society } \\
\text { Advisory Panel }\end{array}$ \\
\hline $\begin{array}{l}\text { Organização para a } \\
\text { Cooperação } \\
\text { Desenvolvimento } \\
\text { Econômico }\end{array}$ & Global & 1961 & 2010 & Consultas \\
\hline
\end{tabular}

Fonte: elaboração própria, a partir de dados secundários. 
Esse mapeamento não exaustivo oferece uma contextualização sobre o status atual dos mecanismos de participação social em organizações e instituições internacionais. Este levantamento tentou reunir informações sobre o máximo possível de organizações, instituições e agências internacionais no que tange à participação social, elencando o ano de criação da organização internacional, o ano de criação ou implementação do mecanismo participativo e as formas de participação dos atores nãoestatais. Das 31 organizações listadas nesta tabela, 12 são globais, sete do continente americano e sete do continente africano. A Ásia conta com três organizações e a Europa, duas.

A maior dificuldade nesta pesquisa de mapeamento se dá em razão da dissonância entre as informações disponíveis no site das respectivas agências, instituições e organizações internacionais e a prática da dinâmica participativa. Isso, muitas vezes, se deve pela falta de atualização dos websites ou também pela própria dinâmica participativa, que acaba sendo esvaziada pela Ol como uma forma de 'sufocamento' da sociedade civil - principalmente naquelas onde há um desacordo entre os Estados sobre a participação social - ou pelos próprios atores não-estatais, que deixam gradualmente de participar dos mecanismos criados.

Dessa forma, este mapeamento se pautou, principalmente, pelas informações disponíveis nos websites das Ol, observando o ano de criação da primeira experiência participativa. Na quase totalidade dos casos, os mecanismos de participação social foram mantidos, de acordo com as informações disponibilizadas pelas OI, o que não necessariamente vai ao encontro da literatura especializada. Um exemplo disso é o caso da participação social na ASEAN. Embora o primeiro mecanismo participativo tenha sido criado em 1979, a literatura tende a enfatizar a dificuldade de participação dos atores não-estatais nessa OI em particular, que possui forte caráter soberanista e estatal, mesmo após o processo de democratização da Ol em 2007 (Chandra, 2006; Gerard, 2014):

Given ASEAN's limited experience in allowing civil society groups to participate in the agenda-setting, it might be difficult for the Association to deal directly with the numerous civil society groups in the region. Another key challenge to civil society engagement with ASEAN is the Association's lack of openness to civil society participation. Less democratic member-countries are still unsure about civil society engagement in the ASEAN process. 
Countries such as Burma, and even Singapore, would wish to stop civil society groups from participating in the Association's decision-making processes (Chandra, 2006).

Há ainda casos de Ols em que não encontramos informações disponíveis sobre mecanismos institucionais de participação. Entre estas estão, a União Aduaneira da África Austral; o Conselho de Cooperação do Golfo; a Comunidade Econômica e Monetária da África Central; Cooperação Econômica Ásia-Pacífico; Banco de Desenvolvimento Caribenho; Banco Interamericano de Desenvolvimento; Fundo de Desenvolvimento Nórdico; Banco Centro-americano de Integração Econômica e Banco de Desenvolvimento do Leste Africano.

No total, foram pesquisadas 40 agências, instituições e organizações internacionais. Abaixo, transformado em gráfico, vemos a porcentagem de Ols que possuem e não possuem mecanismos participativos:

\section{GRÁFICO 1 - Existência de mecanismos participativos em organizações e instituições} internacionais

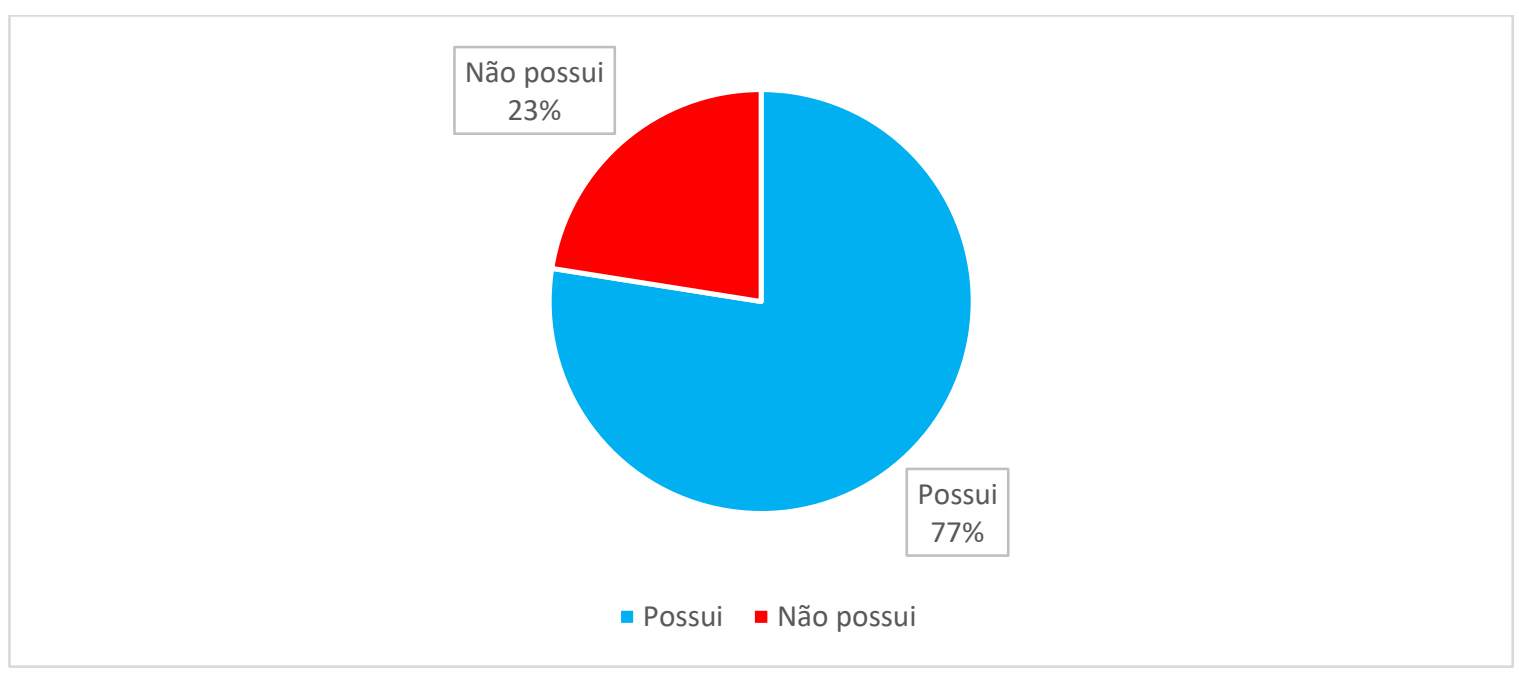

Fonte: elaboração própria, a partir de dados secundários.

Como podemos visualizar nesta análise, grande parte das Ols pesquisadas possuem mecanismos participativos implementados. A partir deste mapeamento, podemos visualizar também, que a maioria dos mecanismos participativos oferecidos aos atores não-estatais são de caráter consultivo e de colaboração. Comparados com outras experiências participativas, como por exemplo no caso brasileiro, os conselhos municipais de saúde e assistência social, podemos perceber um estágio de participação 
social ainda incipiente, visto que, em princípio, os atores governamentais não são levados a deliberarem e formarem consensos com os atores não-estatais em torno das decisões que precisam ser tomadas. Cabe ressaltar, no entanto, que dada a multiplicidade de atores envolvidos e da escassez de informações mais detalhadas, somente estudos de caso de cada agência, instituição e Ol poderia levar a conclusões generalizáveis.

Para além de um aprofundamento da experiência participativa em organizações públicas onde há somente consultas e um relacionamento de colaboração com a sociedade civil, se faz necessário uma ampliação da publicidade no processo decisório daquelas organizações que já contam com mecanismos deliberativos, ou seja, aquelas organizações onde os atores governamentais e não-estatais precisam debater e chegar à um consenso em torno das questões debatidas. Tal publicidade permitiria que as contribuições feitas pelas organizações da sociedade civil durante os debates públicos fossem acompanhadas durante o trajeto institucional, da formulação à implementação das políticas. Dessa forma, possibilitaria que os atores não-estatais percebessem que a sua participação teve influência no processo decisório.

De acordo com Pallas e Uhlin (2014), para que canais de participação sejam acessíveis às organizações da sociedade civil, o processo decisório das organizações deve ser poroso. Duas dimensões da variável 'porosidade' se refere às formas de acesso das organizações da sociedade civil (quantas e quais participam) e a profundidade deste acesso, que se refere a qualidade do engajamento civil, que pode variar de uma forma "rasa", no qual documentos públicos são compartilhados com a sociedade civil, até uma participação mais profunda, que incluiria uma participação total da sociedade civil no processo decisório das organizações públicas. Outro importante elemento que garantia uma participação social mais efetiva se relaciona com os contatos das organizações da sociedade civil (com agentes governamentais e com outras redes ativistas).

Com o objetivo de entender o motivo das organizações da sociedade civil participarem de instituições multilaterais, Fogarty (2011) argumenta que as ONGs internacionais não escolhem estratégias uniformes no sentido de maximizar o impacto político da participação, mas ao invés, as estratégias variariam em função da natureza 
institucional das organizações em que participam, da disponibilidade de recursos que possuem, da ideologia e de suas estruturas organizacionais.

Ao analisar o caso da dinâmica participativa no Mercosul, Alemany e Leandro (2006) argumentam que há vários estágios da participação que precisam ser analisados, onde a informação e a consulta se constituem enquanto somente os dois primeiros passos. Segundo os autores, uma resposta adequada para as limitações da participação social observada no Mercosul passaria pela abertura à novos atores e opiniões, onde se criaria uma nova engenharia institucional a partir das experiências vivenciadas entre 1995-2006.

\section{GRÁFICO 2 - Década de implementação dos mecanismos participativos pesquisados}

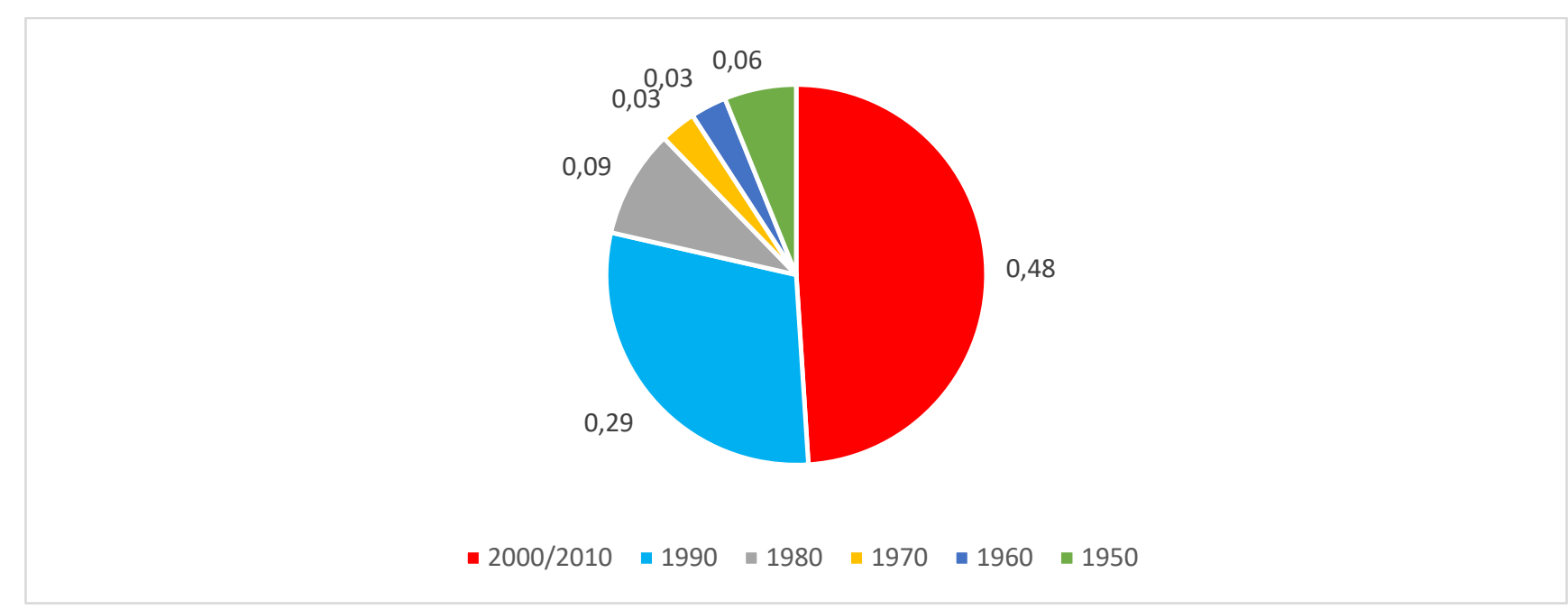

Fonte: elaboração própria, a partir de dados secundários.

A partir da pesquisa, podemos visualizar que os mecanismos participativos empreendidos pelas OI é um fenômeno novo. A maioria dos mecanismos criados pelas Ol que foram pesquisadas data do final da década de 1990 e começo dos anos 2000/2010. Tal fenômeno está intimamente relacionado com a promoção das normas de boa governança, principalmente por parte da ONU, no pós-Guerra Fria. Desde então, a democracia, e consequentemente seus instrumentos e instituições, tem sido fomentados mundo afora.

Como podemos ver nesta análise, grande parte das organizações internacionais possuem mecanismos participativos, seja porque reconheceram a importância desempenhada pelos atores não-estatais no cenário da política internacional, 
reconhecendo que uma governança eficaz seria impossível sem a incorporação destes, seja porque tais organizações sofreram pressões externas para que se democratizassem, abrindo inputs formais para a participação da sociedade civil. A segunda hipótese parece ser a mais verídica. ONGs, redes de ativistas e comunidades epistêmicas tem exercido influência mundo afora para que suas demandas sejam consideradas por Estados e/ou organizações internacionais, geralmente através de mecanismos formais participativos. Exemplo disto foi a atuação do Observatório de Políticas Públicas em Direitos Humanos do Mercosul, uma coalização de doze organizações da sociedade civil, criada em 2004 com o objetivo de monitorar e exercer influência em torno da agenda de direitos humanos no Mercosul. Outra organização ativa no cenário da integração sul-americana é o Fórum da Sociedade Civil nas Américas, uma coalização de ONGs criada em 1997 (Hoffmann, 2015).

Da mesma forma, na Associação de Nações do Sudeste Asiático (ASEAN), a questão dos direitos humanos e da participação social é impulsionada através da atuação de algumas redes de ativistas, ONGs e comunidades epistêmicas, que lutam por uma maior abertura democrática em um ambiente considerado hostil à atuação destes. A luta é travada em meio aos interesses de países não democráticos - notadamente Laos, Vietnã, Mianmar e Camboja, que se opõem abertamente contra a participação social. Entre as organizações mais ativas na integração regional do Sudeste asiático estão o Working Group for an ASEAN Human Rights Mechanism; Asia Pacific Forum of National Human Institutions e Solidarity for Asian People's Advocacy Task Force on ASEAN and Human Rights (Munro, 2011; Durbach et al., 2009; Hara, 2019).

Apesar de todas as debilidades existentes, a mera existência de mecanismos participativos é uma conquista fruto da atuação de inúmeros atores não-estatais mundo afora, que lutaram e lutam por mudanças nas relações entre Estados, organizações internacionais e a sociedade civil. Digno de nota é que países democráticos tendem a impulsionar e a se mostrarem propensos a compartilharem a governança com atores não-estatais em organizações internacionais. De outro lado, países autoritários rejeitam a participação social, visto que esta representa um alto risco de exposição e 'vergonha' ocasionado pelas contundentes críticas levadas pelas 
organizações da sociedade civil à fóruns internacionais, geralmente associada a questão doméstica dos direitos humanos nestes países, o que consequentemente, pode gerar pressões externas por mudanças, algo que contraria os interesses de manutenção do status quo de países autoritários. Ao estudar a ASEAN, Acharya (2003) argumenta que as instituições regionais são produto das estruturas políticas domésticas. Dado que a participação social é fortemente dependente da disposição dos atores governamentais em compartilharem a governança em organizações internacionais e regionais, a questão participativa, assim como a democracia, está sujeita a retrocessos, limitações e pode até mesmo deixar de existir.

\section{CONSIDERAÇÕES FINAIS}

Como analisamos neste artigo, as contradições do mundo contemporâneo fizeram com que os mecanismos da democracia liberal se tornassem insuficientes para representar sociedades cada vez mais complexas e demandantes, em termos políticos. Dessa forma, mecanismos participativos - para além do período meramente eleitoral nas políticas domésticas - foram incorporadas às estruturas organizacionais de diversas instituições e organizações, diante das demandas por uma maior abertura e democratização nos negócios públicos.

A partir da análise, pudemos verificar que os estudos sobre participação de atores não-estatais na arena internacional tendem a ser menos focados na elaboração de métodos para o estudo do objeto participativo, quando comparado com a Ciência Política. Em termos de institucionalização da participação social, esta remonta à criação do Sistema ONU, sendo que o Conselho Econômico e Social das Nações Unidas (ECOSOC) pode ser considerado pioneiro. A primeira Resolução sobre o tema data de 1950, Resolução 288 B (X).

No mapeamento realizado neste artigo foram pesquisadas 40 agências, instituições e organizações internacionais, elencando se há ou não mecanismos participativos previstos na estrutura institucional; o ano de criação do mecanismo participativo e as formas de participação. Como verificamos, $77 \%$ das organizações pesquisadas possuem mecanismos participativos, sendo que a maioria dos mecanismos participativos oferecidos aos atores não-estatais são de caráter consultivo e de colaboração. Também 
concluímos que a maioria dos mecanismos criados pelas organizações internacionais que foram pesquisadas datam do final da década de 1990 e começo dos anos 2000/2010, sendo que tal fenômeno está intimamente relacionado com a promoção das normas de boa governança, principalmente por parte da ONU, no pós-Guerra Fria.

Um ponto importante enfatizado neste artigo é a diferença entre a existência formal de mecanismos participativos - ligados à inclusão e participação - e a participação efetiva, ligados à influência e ao empoderamento por partes dos atores não-estatais. A questão da influência é importante porque está relacionado com a qualidade participativa, ou seja, a participação social, de alguma forma, teve influência sobre o processo decisório da organização em questão? Tais questionamentos são dependentes de estudos empíricos aprofundados para se chegar a conclusões elucidáveis.

Apesar das debilidades em torno da participação de atores não-estatais (falta de capacitação e preparo, falta de financiamento, países contrários à inclusão de atores da sociedade civil, entre outros), vimos que os mecanismos de inputs para a sociedade civil em organizações internacionais é fruto de pressões externas por parte de ONGs, redes de ativistas e comunidades epistêmicas para que as organizações internacionais se democratizassem. Aliado à esta luta, podemos perceber a importância desempenhada por Estados democráticos na implementação de mecanismos participativos para os atores não-estatais. Como argumentamos, visto que a participação social é fortemente dependente da vontade política dos agentes governamentais em compartilharem a governança nas organizações internacionais, a questão participativa é contingente, que oscila conforme o pêndulo da história.

Contemporaneamente, a participação social está cada vez mais ameaçada pela crise do multilateralismo, da falta de legitimidade das organizações internacionais e por um crescente nacionalismo. Segundo Lupel (2019), a crise do multilateralismo se daria em dois níveis. De um lado, representaria o enfraquecimento da ordem internacional liberal, pautado pela democracia, direitos humanos, livre comércio. De outro lado, tal crise resultaria em uma ameaça ao sistema de cooperação multilateral do Sistema ONU. As instituições multilaterais são cada vez menos utilizadas na resolução de 
controvérsias, principalmente por China, Rússia e Estados Unidos, que tem tomado cada vez mais ações unilaterais. As decisões políticas de Donald Trump são símbolos desta questão. Desde que assumiu a presidência em 2017, o país deixou o Conselho de Direitos Humanos da ONU, por acusar a organização de ser anti-Israel; saiu do Acordo de Paris sobre mudanças climáticas; retirou o país do Acordo Nuclear com o Irã e travou uma Guerra Comercial com a China. De outro lado, a China tem construído governanças paralelas, como por exemplo, a Organização de Cooperação de Xangai.

Este cenário de crise do multilateralismo é acompanhado por uma ascensão de nacionalismos ao redor do mundo, notadamente nos Estados Unidos, Brasil, Reino Unido, Leste europeu, entre outros, que veem a globalização e as instituições multilaterais como ilegítimas no cenário da governança global. As principais críticas geralmente giram em torno da ineficiência das organizações internacionais e do caráter ideológico ao qual estariam envoltas. Diante deste cenário descrito, a questão da participação social parece cada vez mais sufocada. Exemplo disto é o caso brasileiro, onde por meio do decreto 9.759 de 2019, o presidente Jair Bolsonaro diminuiu de 700 para menos de 50 o número de conselhos previstos pela Política Nacional de Participação Social (SNPS) (Rede Brasil Atual, 2019).

Perante este cenário, cabe aos atores não-estatais utilizar todas as técnicas, recursos e aprendizados que dispõem para continuar lutando por organizações públicas cada vez mais democráticas e abertas à sociedade civil. A história nos dirá sobre os influxos destas lutas.

\section{REFERÊNCIAS}

Acharya, A. (1997). 'Ideas, identity, and institution-building: from the 'ASEAN way' to the 'Asia-Pacific way'?'. The Pacific Review, 10 (3), pp. 319-346, [online]. Disponível em: https://www.tandfonline.com/doi/abs/10.1080/09512749708719226. [Acesso em: 01 Jun. 2020].

Acharya, A. (2003). 'Democratisation and the prospects for participatory regionalism in Southeast Asia'. Third World Quarterly, 24 (2), pp. 375-390, [online]. Disponível em: https://www.jstor.org/stable/3993518. [Acesso em: 01 Jun. 2020].

Aguilar, W. A. (2017). Participación ciudadana en la UNASUR. La Paz: CEDLA.

Alemany, C; Leandro, B. (2006). Análisis y propuestas para la participación ciudadana en el Mercosur. Uruguai: Friedrich Ebert Stiftung. 
Almeida, D. R. de. (2009). 'Teoria e prática deliberativas: um olhar sobre os conselhos municipais de saúde', in: L. Avritzer (Org.), Democracia, desigualdades e políticas públicas no Brasil. Belo Horizonte: Projeto Democracia Participativa.

Asplund, A. (2014). 'ASEAN Intergovernmental Commission on Human Rights: civil society organizations limited influence on ASEAN'. Journal of Asian Public Policy, 7 (2), pp. 191-199. Disponível em: https://doi.org/10.1080/17516234.2014.896090. [Acesso em: 01 Jun. 2020].

Avritzer, L. (2006). 'New Public Spheres in Brazil: Local Democracy and Deliberative Politics'. International Journal of Urban and Regional Research, 30 (3), pp. 623-637, [online]. Disponivel em: http://bibliotecadigital.fgv.br/ojs/index.php/revdireitogv/article/view/35246. [Acesso em: 21 Abr. 2020].

Avritzer, L. (2008). 'Instituições participativas e desenho institucional: algumas considerações sobre a participação no Brasil democrático'. Revista Opinião Pública, 14 (1), pp. 43-64, [online]. Disponível em: http://www.scielo.br/pdf/op/v14n1/02.pdf. [Acesso em: 21 Abr. 2020].

Bache, I.; Flinders, M. (2004). Multi-level governance. Oxford: Oxford University Press.

Barber, B. (1984). Strong democracy: participatory politics for a new age. California: University of California Press.

Budini, T. F. (2015). Encontros com o Mercosul: a atuação de organizações da sociedade civil brasileira na integração regional. Tese de Doutorado, Ciência Política/Universidade de São Paulo.

Bülow, M. V. (2010). Building Transnational Networks: civil society and the politics of trade in the Americas. Cambridge: Cambridge University Press.

Carrillo, F. S. (2013). Sociedad Civil e Integración Centroamericana. San Salvador: Fundación ETEA.

Chandra, A. (2006). 'The Role of Non-State Actors in ASEAN'. Revisiting Southeast Asian Regionalism, pp. 71-81, [online]. Disponível em: https://www.alternativeregionalisms.org/wp-content/uploads/2009/09/chandra non-stateactorsinasean.pdf.

[Acesso em: 21 Abr. 2020].

Colás, A. (2002). International Civil Society: Social Movements in World Politics. Cambridge: Polity Press.

Cox, R. (1999). 'Civil society at the turn of the millennium: prospects for an alternative world order'. Review of International Studies, 25 (1), pp. 3-28, [online]. Disponível em: https://doi.org/10.1017/S0260210599000042. [Acesso em: 01 Jun. 2020].

Creighton, J. (2005). The public participation handbook: making better decisions through citizen involvement. San Francisco: Jossey-Bass. 
Dagnino, E. (2002). Sociedade civil e espaços públicos no Brasil. São Paulo: Paz e Terra.

Dagnino, E.; Tatagiba, L. (2007). Democracia, sociedade civil e participação. Chapecó: Argos.

Dahl, R. (2012). A democracia e seus críticos. São Paulo: Martins Fontes.

Della Porta, D. (2013). Can democracy be saved? Participation, deliberation and social movements. Cambridge: Polity Press.

Della Porta, D; Tarrow, S. (2005). Transnational Protest and Global Activism: people, passions, and power. Oxford: Rowman \& Littlefield Publishers.

Dryzek, J. (2002). Deliberative democracy and beyond: liberals, critics, contestations. Oxford: Oxford University Press.

Durbach, A; Renshaw, C; Byrnes, A. (2009). 'A tongue but no teeth?': The emergence of a regional human rights mechanism in the Asia Pacific Region'. Sydney Law Review, 31 (2), p. 211- 238, [online]. Disponível em: https://papers.ssrn.com/sol3/papers.cfm?abstract id=1459863. [Acesso em: 01 Jun. 2020].

Ecosoc. (1996). Resolution 1996/31: Consultative Relationships between the United Nations and non-governmental organizations. Disponível em: https://www.un.org/esa/coordination/ngo/Resolution 1996 31/. (Acesso em: 21 Abr. 2020).

Faria, C. F. S. de. (2011). O parlamento participativo do século XXI: pode o povo ajudar os parlamentares a fazerem leis melhores? Tese de Doutorado, Ciência Política/Universidade Estadual do Rio de Janeiro.

Fogarty, E. (2011). 'Nothing Succeeds Like Access? NGO Strategies Towards Multilateral Institutions'. Journal of Civil Society, 7 (2), pp. 207-227, [online]. Disponível em: https://doi.org/10.1080/17448689.2011.573670. [Acesso em: 01 Jun. 2020].

Freedom House. (2020). Nations in transition 2020: Dropping the Democratic Façade. Disponível em: https://freedomhouse.org/sites/default/files/202004/05062020 FH NIT2020 vfinal.pdf. (Acesso em: 01 Jun. 2020).

Gerard, K. (2014). 'Explaining ASEAN's Engagement of Civil Society in Policy-making: smoke and mirrors'. Globalizations, 12 (3), pp. 365-382, [online]. Disponível em: https://research-repository.uwa.edu.au/en/publications/explaining-aseansengagement-of-civil-society-in-policy-making-sm. [Acesso em: 21 Abr. 2020].

Gutmann, A.; Thompson, D. (2004). Why Deliberative Democracy? Princeton: Princeton University Press.

Habermas, J. (2001). Constelação pós nacional: ensaios políticos. São Paulo: Littera Mundi. 
Habermas, J. (2003). Direito e Democracia: entre facticidade e validade. Rio de Janeiro: Tempo Brasileiro, vol. 2.

Habermas, J. (2012). Sobre a Constituição da Europa: um ensaio. São Paulo: Editora da UNESP.

Haacke, J. (1999). 'The concept of flexible engagement and the practice of enhanced interaction: Intramural challenges to the 'ASEAN way'. Pacific Review, 12 (4), pp. 581, 611, [online]. Disponível em: https://doi.org/10.1080/09512749908719307. [Acesso em: 01 Jun. 2020].

Hall, S. (2006). A identidade cultural na pós-modernidade. São Paulo: Lamparina.

Hara, A. E. (2019). 'The struggle to uphold a regional human rights regime: the winding role of ASEAN Intergovernmental Commission on Human Rights (AICHR)'. Revista Brasileira de Política Internacional, 62 (1), pp. 1-19, [online]. Disponível em: https://www.scielo.br/pdf/rbpi/v62n1/1983-3121-rbpi-62-1-e011.pdf. [Acesso em: 01 Jun. 2020].

Hoffmann, A. R. (2015). 'At Last: Protection and Promotion of Human Rights by Mercosur', in T. A. Börzel; V. V. Hüllen (eds.), Governance Transfer by Regional Organizations: Patching Together a Global Script. New York: Palgrave Macmillan, pp. 192- 208.

Hsien-li, T. (2011). The ASEAN Inter-Governmental Commission on Human Rights: Institutionalising Human Rights in Southeast Asia. Cambridge: Cambridge University Press.

Kaldor, M. (2003). 'The idea of global civil society'. International Affairs, 79 (3), pp. 583593, [online]. Disponível em: https://www.jstor.org/stable/3569364. [Acesso em: 01 Jun. 2020].

Kant, I. (1995). A paz perpétua e outros opúsculos. Lisboa: Edições 70.

Karns, M; Mingst, K. (2010). International Organizations: the politics and processes of global governance. Boulder: Lynne Rienner Publishers.

Keck, M; Sikkink, K. (1998). Activists beyond borders: advocacy networks in international politics. London: Cornell University Press.

Keohane, R; Nye, J. (1977). Power and Interdependence. New York: Longman, 1977.

Lavalle, A. G.; Houtzager, P.; Castello, G. (2006). 'Representação política e organizações civis: novas instâncias de mediação e os desafios da legitimidade'. Revista Brasileira de Ciências Sociais, 21 (60), pp. 43-66, [online]. Disponível em: http://www.scielo.br/pdf/rbcsoc/v21n60/29760.pdf. [Acesso em: 21 Abr. 2020].

Lemke, T. E. S. (2006). A Human Rights Watch: formas de atuação das organizações não-governamentais transnacionais. Tese de Doutorado, Ciências Sociais/Pontifícia Universidade Católica de São Paulo. 
Linklater, A. (1998). 'The transformation of political community: ethical foundations of the post-Westphalian era'. Columbia: University of South Carolina Press.

Lipschutz, R. D. (1992). 'Reconstructing World Politics: The Emergence of Global Civil Society'. Millennium: Journal Of International Studies, 21 (3), pp. 389-420, [online]. Disponível em: https://journals.sagepub.com/doi/10.1177/03058298920210031001. [Acesso em: 01 Jun. 2020].

Löblová, O. (2017). 'When epistemic communities fail: exploring the mechanism of policy influence', 46 (1), pp. 160-189, [online]. Disponível em: https://onlinelibrary.wiley.com/doi/abs/10.1111/psj.12213. [Acesso em: 01 Jun. 2020].

Lupel, A. (2019). 'Two Tasks to Get Past the Crisis of Multilateralism'. Global Observatory, [online]. Disponível em: https://theglobalobservatory.org/2019/08/twotasks-get-past-crisis-multilateralism/. [Acesso em: 01 Jun. 2020].

Manin, B. (1997). The principles of representative government. New York: Cambridge.

Matlosa, K.; Lotshwao, K. (2006). Political integration and democratisation in Southern Africa: progress, problems and prospects. Johannesburg: EISA.

Mckeon, N. (2009). The United Nations and Civil Society: legitimating global governance - whose voice? London: Zed Books.

Menezes, F. de. (2010). As inter-relações entre os atores internacionais: o caminho à cooperação. São Paulo: Editorama.

Miguel, L. F. (2005). 'Teoria democrática atual: esboço de mapeamento'. BIB, 59, pp. 542, [online]. Disponível em: http://www.anpocs.com/index.php/edicoes-anteriores/bib59/569-teoria-democratica-atual-esboco-de-mapeamento/file. [Acesso em: $21 \mathrm{Abr}$. 2020].

Moyo, B. (2007). Civil Society Organisations' engagement with regional economic communities in Africa: People friendly or people driven? Final Report Submitted to UNDP regional Service Centre for Eastern and Southern Africa.

Munro, J. (2011). 'The relationship between the origins and regime design of the ASEAN Intergovernmental Commission on Human Rights (AICHR)'. The International Journal of Human Rights, 15 (8), pp. 1185-1214, [online]. Disponível em: https://doi.org/10.1080/13642987.2010.511996. [Acesso em: 01 Jun. 2020].

Oliveira, O. P. (2016). 'Mecanismos da difusão global do orçamento participativo: indução internacional, construção social e circulação de indivíduos'. Opinião Pública, 22 (2), pp. 219-249, [online]. Disponível em: https://www.scielo.br/pdf/op/v22n2/18070191-op-22-2-0219.pdf. [Acesso em: 01 Jun. 2020].

Pallas, C; Uhlin, A. (2014). 'Civil Society Influence on International Organizations: Theorizing the State Channel'. Journal of Civil Society, 10 (2), pp. 184, 203, [online]. 
Disponível em: https://doi.org/10.1080/17448689.2014.921102. [Acesso em: 01 Jun. 2020].

Pateman, C. (1992). Participação e teoria democrática. Rio de Janeiro: Paz e Terra.

Paul, J. A. (2012). 'Civil Society and the United Nations', in H. Moksnes; M. Melin (eds.), Global Civil Society Shifting Powers in a Shifting World. Villavägen: Uppsala Centre for Sustainable Development, pp. 63-81.

Pogrebinschi, Thamy. (2017). Latinno Dataset. Berlin: WZB.

Quayle, L. (2012). 'Bridging the gap: an 'English School' perspective on ASEAN and regional civil society'. The Pacific Review, 25 (2), pp. 199-222, [online]. Disponível em: https://www.tandfonline.com/doi/abs/10.1080/09512748.2012.658848?src=recsys\&jo urnalCode=rpre20. [Acesso em: 21 Abr. 2020].

Ramanzini, I. G. G. (2014). O prometido é devido: compliance no sistema interamericano de direitos humanos. Tese de Doutorado, Relações Internacionais/Universidade de São Paulo.

Ramanzini Júnior, H.; Farias, R. de S. (2014). 'Missão impossível? Mercosul, participação social e política externa no Brasil'. Pensamiento Proprio, 40, pp. 355-374, 2014, [online]. Disponível em: http://www.cries.org/wp-content/uploads/2015/03/019-Ramanzini.pdf. [Acesso em: 21 Abr. 2020].

Rede Brasil Atual. (2019). Decreto de Bolsonaro extingue canais de participação social em políticas públicas, 12 de abril de 2019. Disponível em: https://www.redebrasilatual.com.br/politica/2019/04/decreto-de-bolsonaro-extingueorgaos-de-participacao-popular/. [Acesso em: 01 Jun. 2020].

Risse-Kapen, T. (1995). Bringing transnational relations back in: non-state actors, domestic structures and international institutions. Cambridge: Cambridge University Press.

Rodrigues, G.; Maciel, T. M. (2014). 'A participação da sociedade civil nas Organizações Internacionais Regionais (OIR) da América Latina e Caribe'. Pensamiento Proprio, 40, pp. 321-353, [online]. Disponível em: http://www.cries.org/wpcontent/uploads/2015/03/018-Gilberto.pdf. [Acesso em: 21 Abr. 2020].

Rosenau, J. (2004). 'Strong demand, huge supply: governance in emerging epoch', in I. Bache e M. Flinders (eds.), Multi-level Governance. Oxford: Oxford University Press, pp. 31-48.

Ruhlman, M. (2015). Who participates in global governance? States, bureaucracies, and NGOs in the United Nations. London: Routledge Taylor \& Francis Group.

Santos, W. G. dos. (1998). 'Poliarquia em 3D'. Dados, 41 (2), pp. 207-281, [online]. Disponível em: http://www.scielo.br/scielo.php?pid=S001152581998000200001\&script=sci abstract. [Acesso em: 21 Abr. 2020]. 
Scholte, J. A. (2002). 'Civil society and democracy in global governance'. Global Governance, 8 (3), pp. 281-304, [online]. Disponível em: https://www.jstor.org/stable/27800346. [Acesso em: 01 Jun. 2020].

Serbin, A. (2013). 'Atuando sozinho? Governos, sociedade civil e regionalismo na América do Sul'. Lua Nova, 90, pp. 297-327, [online]. Disponível em: http://www.scielo.br/pdf/In/n90/a11n90.pdf. [Acesso em: 21 Abr. 2020].

Sikkink, T. (1993). 'Human Rights, Principles, Issue-Networks, and Sovereignty in Latin America'. International Organization, 47 (3), pp. 411-441, [online]. Disponível em: https://www.jstor.org/stable/2706982?seq=1. [Acesso em: 01 Jun. 2020].

Tarrow, S. (2005). The New Transnational Activism. Cambridge: Cambridge University Press.

Teixeira, E. C. (2001). O local e o global: limites e desafios da participação cidadã. São Paulo: Cortez.

The Economist Intelligence Unit. (2019). Democracy Index 2019: a year of democratic setbacks and popular protest. Disponível em: https://www.in.gr/wpcontent/uploads/2020/01/Democracy-Index-2019.pdf. (Acesso em: 01 Jun. 2020).

Towns, A; Rumelili, B. (2017). 'Taking the pressure: unpacking the relation between norms, social hierarchies, and social pressures on states'. European Journal of International Relations, 23 (4), pp. 756-779, [online]. Disponível em: https://journals.sagepub.com/doi/10.1177/1354066116682070. [Acesso em: 01 Jun. 2020].

United Nations. (1945). UN Charter. Disponível em: https://www.un.org/en/sections/un-charter/un-charter-full-text/. (Acesso em: 21 Abr. 2020).

V-Dem Institute. (2020). Autocratizion Surges - Resistance Grows: Democracy Report 2020. Disponível em: https://www.v-dem.net/media/filer public/fo/5d/f05d46d8-626f4b20-8e4e-53d4b134bfcb/democracy report 2020 low.pdf. Acesso em: 01 Jun. 2020).

Young, I. M. (2000). Inclusion and democracy. Oxford: Oxford University Press. 